\title{
The execution of minors
}

\author{
Simon WeSSEly, Honorary Lecturer in Forensic Psychiatry, Institute of Psychiatry, \\ De Crespigny Park, London SE5 8AF
}

We all know that American psychiatry is different from ours, but just how different was shown by a recent symposium at the American Psychiatric Association in New York on 14 May 1990, entitled 'Capital Crime and Capital Punishment in Minors'.

Of the 50 US states, 37 now permit the death penalty, but only 18 set a lower age limit (usually 18 , but in five 16). This leaves 19 that theoretically permit the execution of minors of any age. Recently the Supreme Court overturned the death penalty on William Thompson, then aged 15, who had murdered his brother-in-law. However, they declined to rule it was unconstitutional to execute minors under 18 , thus paving the way for the possible execution of at least a hundred teenagers currently on Death Row.

Richard Bonnie, a lawyer from the Department of Psychology and Law at the University of Virginia, pointed out that of those juveniles either executed during this century, or currently on Death Row, nearly all are black, and come from the old South. Nearly all their victims were white. The difference between four years in a juvenile correction facility and death was decided quite arbitrarily by the local boundary between Juvenile and Adult Court jurisdictions.

Wade Myers, a psychiatrist from Florida, next refuted the argument that juveniles should be executed because they are incapable of reform, giving examples of successful rehabilitation of several juveniles accused of capital crime. Next John Schowalter, Professor of Child Psychiatry at Yale, showed how in all states the possibility for mitigation on psychiatric grounds exists, usually on the basis of so-called developmental delay and/or neuropsychiatric abnormalities. Yet Schowalter argued that all juveniles were developmentally delayed, in the sense of not being adults. Furthermore, nearly all of a sample of juveniles on Death Row had multiple psychiatric handicaps. How then can anyone decide who is, and who is not, developmentally delayed? The same applies to adults - many of the adults executed in the USA were also developmentally delayed with neuropsychiatric disabilities. Schowalter argued that one of the reasons for retaining the death penalty in juveniles was the fear of creating a loophole for adults. He also used historical examples of what adults have written about the death penalty in children to illustrate how views on responsibility varies according to social mores. He concluded that retention of the death penalty is more to do with developmental issues in adults than children.

It was encouraging to note that the speakers, including the next President of the APA, made their dislike of the current practice plain. This was also extended to the death penalty per se, since all the arguments against the death penalty in children (its arbitrariness, injustice, lack of deterrence and propensity for executing disturbed black juveniles from the Deep South) apply equally to adults. Coincidentally a leader in the New York Times later that week (18 May 1990) asked rhetorically about the origins of the American "enthusiasm for execution". The United States is the only Western nation that retains the death penalty, and one of few anywhere that allows the execution of minors - this was not permitted even in the Soviet Union, which, in an adjacent room back at the APA, was still being accused of human rights violations.

However, other forces are also at work. Forensic psychiatrists are now being increasingly asked, and agreeing, to assess the mental health of those facing execution, the "competency to be executed" issue. If the psychiatrist gives them a clean bill of mental health the person can be executed. If not, then the psychiatrist may be asked to treat ("restore their competency"), so they can then be executed, albeit in good mental health. It has been argued that psychiatrists can ethically participate in such activity, and guidelines have been proposed on how to carry out such examinations. The American Psychiatric Association has been unable to decide on the issue.

Meanwhile, America's "enthusiasm for execution" accelerates. Recent candidates for high office have displayed photographs of those whose executions they have authorised, while in California a candidate's election commercial finished by the electric chair. Finally, a ten year old has just gone on trial in Pennsylvania accused of murdering a seven year old. He faces the death penalty. Professor Bonnie said that this particular child will not be executed, but concluded that something is wrong with a system that even contemplates such an act. 